\begin{tabular}{|c|c|}
\hline $\begin{array}{l}\text { 2. To: (Receiving Organization) } \\
\text { Distribution }\end{array}$ & $\begin{array}{l}\text { 3. From: (originating Organization) } \\
\text { Process Engineering Analysis }\end{array}$ \\
\hline $\begin{array}{l}\text { 5. Proj./Prog./Dept./Div.: } \\
74 A 50\end{array}$ & $\begin{array}{l}\text { 6. Design Authority/ Design Agent/Cog. } \\
\text { Engr.: } \\
\text { D. M. Ogden }\end{array}$ \\
\hline
\end{tabular}

8. Originator Remarks:

Approval/Release

4. Related EDT No.: Process Engineering Analys is $\mathrm{N} / \mathrm{A}$

7. Purchase Order No.: N/A

9. Equip./Component No.: $N / A$

10. System/Bldg./Facility: $N / A$

11. Receiver Remarks: 11A. Design Baseline Document? [] Yes [X] No 12. Major Assm. Dwg. No.: $N / A$

13. Permit/Permit Application No.: $N / A$

14. Required Response Date:

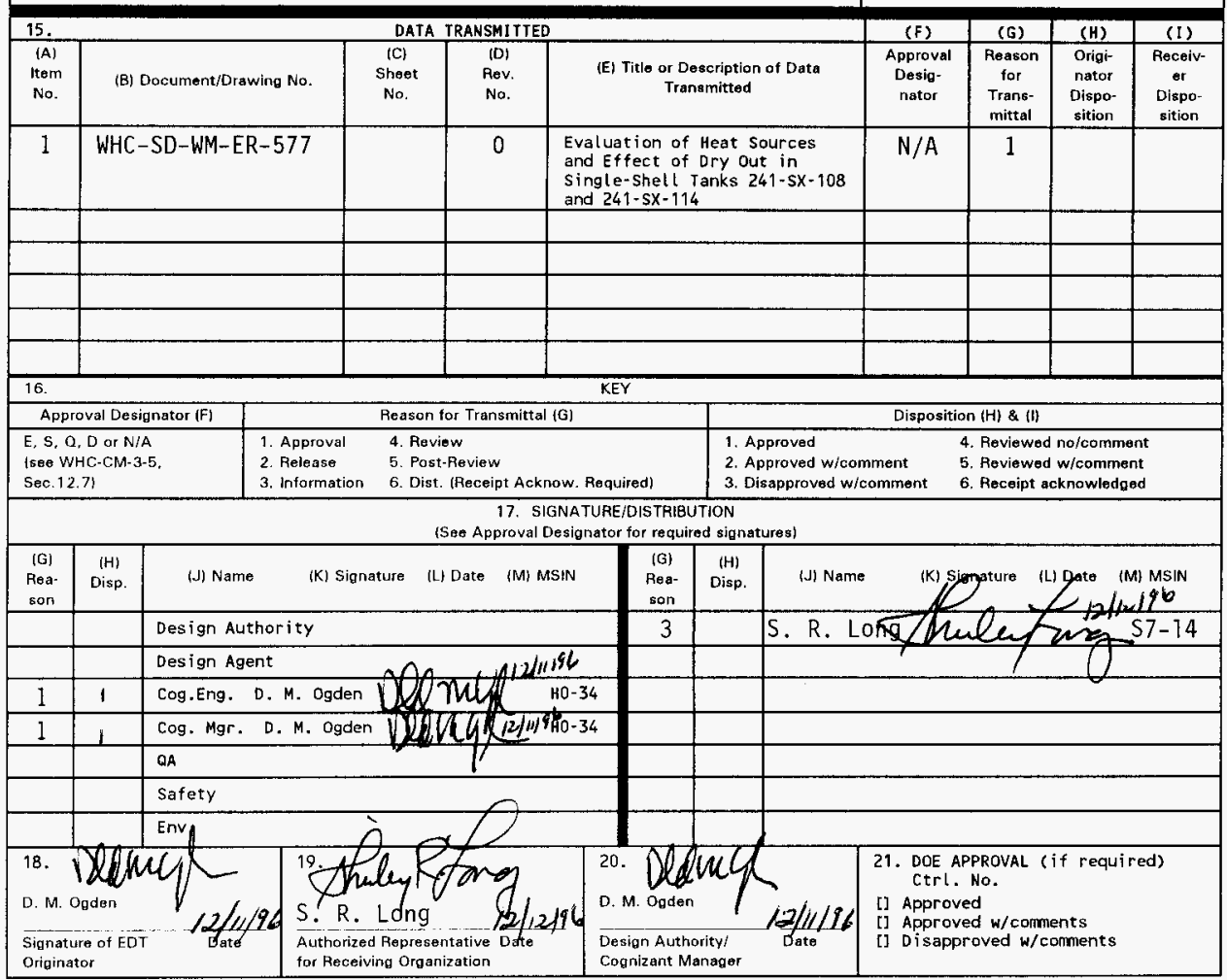

80-7400-172-2(05/96) GEF097 


\title{
Evaluation of Heat Sources and Effect of Dry Out in Single-Shell Tanks 241-SX-108 and 241-SX-114
}

\author{
D. M. Ogden \\ Westinghouse Hanford Company, Richland, WA 99352 \\ U.S. Department of Energy Contract DE-AC06-87RL10930 \\ EDT/ECN: 614691 \\ UC: 2020 \\ Org Code: 74A50 \\ Charge Code: N2218 \\ B\&R Code: EW3135040 \\ Total Pages: 25 \\ Key Words: Single-Shell Waste Tank \\ Dry Out \\ Temperatures
}

Abstract: This report examines two tanks on the list of Single-Shell Tanks with High Heat Loads. This report assesses the maximum temperatures that might exist in the two tanks 241-SX-108 and 241-SX-114. In addition to assessing current conditions in the tanks, the effect of the drying out of the center of the tank on the maximum temperature in the waste and concrete was evaluated. A reassessment of the heat loads was also done using more recent temperature and psychrometric data obtained from these two tanks.

TRADEMARK DISCLAIMER, Reference herein to any specific comercial product, process, or service by trade name, trademark, manufacturer, or otherwise, does not necessarily constitute or imply its endorsement, recommendation, or favoring by the United States Government or any agency thereof or its contractors or subcontractors.

Printed in the United States of America. To obtain copies of this document, contact: WHC/BCS Document Control Services, P.O. Box 1970, Mailstop H6-08, Richland WA 99352, Phone (509) 372-2420; Fax (509) 376-4989.
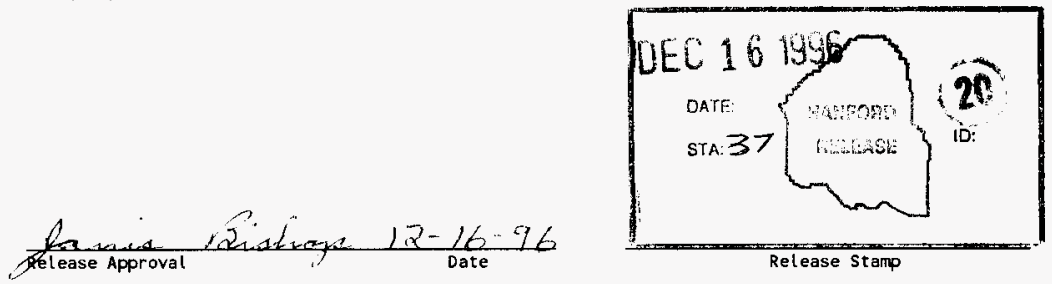


\section{EVALUATION OF HEAT SOURCES AND EFFECT OF DRY OUT}

IN SINGLE-SHELL TANKS 24I-SX-108 AND 241-SX-114

September 1996

Prepared By:
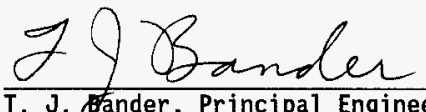

Process Engineering Analysis

Date: $\quad \frac{9 / 23 / 96}{1 / 2}$

Approved By: $\frac{\text { Ded }}{\begin{array}{l}\text { D. M. Ogden, Tear Leader } \\ \text { Process Engineering Analysis }\end{array}}$ Date: $12 / 11 / 96$ 
WHC-SD-WM-ER-577

Rev. 0

\section{CONTENTS}

1.0 INTRODUCTION . . . . . . . . . . . . . . . . . . . . . 1

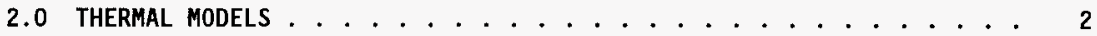

3.0 CASES ANALYZED . . . . . . . . . . . . . . . . . . . . 3

4.0 THERMAL ANALYSIS RESULTS . . . . . . . . . . . . . . . . . 4

4.1 TANK 241-SX-108 .................... . . . 5

4.2 TANK SX-114 .................... . . . 6

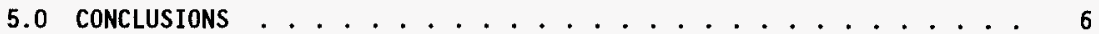

6.0 RECOMMENDATIONS . . . . . . . . . . . . . . . . 7

7.0 REFERENCES . . . . . . . . . . . . . . . . . . . . . 17

\section{LIST OF FIGURES}

1. Entire Thermal Model for 1 Million gal Single-Shell Tank . . . . . 8

2. SX-Tank Thermal Model...................... g

3. SX-Tank Thermal Model ....................... . . 10

4. Tank SX-108 Measured Temperatures . . . . . . . . . . . . . . . . . . 11

5. Tank SX-114 Measured Temperatures. . . . . . . . . . . . . . . . . . 12

6. Tank $S X-108$ Calculated Temperature ................ . . 13

7. Tank SX-108 Calculated Temperatures . . . . . . . . . . . . . . . . . 14

8. Tank SX-114 Calculated Temperature ................. . 15

9. Tank SX-114 Calculated Temperatures . . . . . . . . . . . . 16

\section{LIST OF TABLES}

1. Current Tank Properties . . . . . . . . . . . . . . . . . . . . 1

2. Thermal Properties ....................... . 3

3. Total Heat Source, Soil and Waste Conductivity, and Maximum Waste and Concrete Temperature ................ . 5 
WHC-SD-WM-ER-577

Rev. 0

\section{EVALUATION OF HEAT SOURCES AND EFFECT OF DRY OUT IN SINGLE-SHELL TANKS 241-SX-108 AND 241-SX-114}

\subsection{INTRODUCTION}

This report examines two tanks on the list of Single-Shell Tanks (SST) with High Heat Loads $(>40,000 \mathrm{Btu} / \mathrm{h})$ (Hanlon 1996) with measured temperatures above $190^{\circ} \mathrm{F}$. The heat loads listed in column 2 of Table 1 were evaluated as of 1988 (Hanlon 1996, Table A-5) and are based on several reports summarized by Gibby 1989 . Column 3 of Table 1 gives the total heat source of each tank decayed to 1994 using the $28.6 \mathrm{yr}$ half-life of strontium 90, which comprises the majority of the radioactive material in these waste tanks. Heat loads using recent analyses (Bander 1994) on these tanks are listed in column 4. The volumes are taken from Hanlon 1996.

Table 1. Current Tank Properties.

\begin{tabular}{|c|c|c|c|c|c|}
\hline \multirow[b]{2}{*}{ Tank } & \multicolumn{3}{|c|}{ Total Heat Source $(1000 \mathrm{Btu} / \mathrm{h})$} & \multirow{2}{*}{$\begin{array}{l}\text { Waste } \\
\text { depth }^{1} \\
(\mathrm{ft})\end{array}$} & \multirow{2}{*}{$\begin{array}{c}\text { Solids } \\
\text { Volume } \\
\left(\text { Kgal } \mathrm{ft}^{3}\right)\end{array}$} \\
\hline & $\begin{array}{l}\text { Han 1 on } \\
(1988)\end{array}$ & $\begin{array}{l}\text { (Decayed } \\
\text { to 1994) } \\
\end{array}$ & $\begin{array}{l}\text { Bander } \\
\text { (1994) }\end{array}$ & & \\
\hline $5 X-108$ & 45 & 39 & 39 & 3.1 & 11,700 \\
\hline$S X-114$ & 58 & 50 & 50 & 5.9 & 24,200 \\
\hline
\end{tabular}

1: Depth at center of tank

The ventilation system in the $S X$ farm has been in service since 1954 and needs to be upgraded. If at all possible rather than upgrade the ventilation system it would be desirable to completely shut the system off. However there is a concern that temperatures in some of the SX tanks would exceed the Limiting Conditions for Operations (LCO) temperature 1 imit, which is $300^{\circ} \mathrm{F}$ (Dougherty 1996). This report assesses the maximum temperatures that might exist in the two tanks 241-SX-108 and 241-SX-114. In addition to assessing current conditions in the tanks, the effect of the drying out of the center of the tank on the maximum temperature in the waste and concrete was evaluated. A reassessment of the heat loads was also done using more recent temperature and psychrometric data obtained from these two tanks. 
Rev. 0

\subsection{THERMAL MODELS}

The finite element model of the SST structure and the surrounding soil was constructed using PATRAN ${ }^{1}$ (PATRAN 1990), a computer code for creating and analyzing finite element and finite difference models. The thermal analyses used P/THERMAL ${ }^{2}$ (P/THERMAL 1991), a thermal analysis package for solving steady-state and transient problems. Results were post-processed using PATRAN. The thermal radiation view factors utilized in these analyses were calculated with P/VIEWFACTOR ${ }^{3}$ (P/VIEWFACTOR 1991), a computer code closely integrated with P/THERMAL. An emissivity of 0.9 (Kreith 1959) is used for all of the surfaces in the tank. The flow of air through the tank from the active ventilation is modeled with an advective heat transfer element from the tank air volume to the outside air.

The boundary conditions on the soil surfaces are shown in Figure 1. An average annual air temperature of $53^{\circ} \mathrm{F}$ (Stone et al. 1983) is used for the outside ambient air. The energy loss to the atmosphere through the soil surface is modeled using a forced convective heat transfer coefficient of $2 \mathrm{Btu} /\left(\mathrm{h} \mathrm{ft} \mathrm{f}^{2} \mathrm{~F}\right)$ (Bander 1992) at the ground surface, which is based on an average wind speed of $7.7 \mathrm{mi} / \mathrm{h}$ across the surface (Stone et al. 1983). An isothermal boundary of $55^{\circ} \mathrm{F}$ (Bander 1992) is employed at the water table $200 \mathrm{ft}$ below the ground surface. The axisymmetric model assumes an adiabatic boundary condition at the outer cylinder of the soil at a radius of $60 \mathrm{ft}$. The $75 \mathrm{ft}$ diameter tanks were built with a distance of $102 \mathrm{ft}$ between centers of tanks. The $60 \mathrm{ft}$ radius provides more soil for heat absorption than a typical tank would have, thus a higher total heat source would be required to attain the temperatures inside the tank. This gives some conservatism to the thermal models used in estimating the total heat source.

A separate model was developed for each tank. The heat source is assumed to be linearly distributed in the waste with the bottom a factor of 2 higher than the top. The main method for evaluating the heat source was a comparison of measured temperatures from thermocouples (TC) in the waste with calculated temperatures from the thermal models. The 1 inearly varying heat source was needed in order to obtain the nearly linear temperature profile as measured by the TC trees. The thermal properties of the various materials in the models are shown in Table 2. The dry waste thermal conductivity of $0.083 \mathrm{Btu} / \mathrm{h}-\mathrm{ft}-{ }^{\circ} \mathrm{F}$ is based on the minimum thermal conductivity measured on waste from 12 tanks (Bouse 1975). Average waste thermal conductivities of 0.25 to $0.32 \mathrm{Btu} / \mathrm{h}-\mathrm{ft}-{ }^{\circ} \mathrm{F}$ were obtained by matching the slopes of the temperature profiles in the waste tanks. Since steady-state thermal solutions were obtained, only thermal conductivity is relevant.

\footnotetext{
${ }^{1}$ PATRAN is a registered trademark of the MacNeal-Schwendler Corporation.

${ }^{2} \mathrm{P} /$ THERMAL is a registered trademark of the MacNeal-Schwendler Corporation.

${ }^{3}$ P/VIEWFACTOR is a registered trademark of the MacNeal-Schwendler Corporation.
} 
WHC-SD-WM-ER-577

Rev. 0

Table 2. Thermal Properties.

\begin{tabular}{|l|c|}
\hline \multicolumn{1}{|c|}{ Material } & $\begin{array}{c}\text { Thermal conductivity } \\
\left.\mathrm{Btu} / \mathrm{h} \mathrm{ft}{ }^{\circ} \mathrm{F}\right)\end{array}$ \\
\hline \hline Air & 0.016 \\
\hline Concrete & 0.435 \\
\hline Soil (dry) & 0.152 \\
\hline Soil (average) & 0.484 \\
\hline Waste (very Dry) & 0.083 \\
\hline Waste (average) & $0.25-0.32$ \\
\hline
\end{tabular}

SSTs in the SX-Tank Farm have one million gallon capacities and a dished bottom. Figure 2 shows the thermal model in the region of a SX tank. There are eight TC trees in each of the SX tanks. However, only trees \#2 and \#8 are currently being recorded on a regular basis. Tree \#2 is about $30 \mathrm{ft}$ from the center of the tank and tree \#8 is about $20 \mathrm{ft}$ from the center of the tank. The tank bottom at the location of trees $\# 2$ and $\# 8$ are $0.8 \mathrm{ft}$ and $0.3 \mathrm{ft}$, respectively, higher than the bottom center of the tank.

Figure 3 shows the thermal model with a $10 \mathrm{ft}$ radius dried out section in the center of the tank. This model was used to analyze the effect of a dry zone in the center of the tank, which has a reduced thermal conductivity.

Five years of temperature data (1990 through 1994) were averaged to obtain the temperature distributions for TC trees \#2 and \#8 of each tank. The TCs from all of the trees have been manually read occasionally. Figure 4 shows the 5 year averaged data and the data for all the trees taken on March 25, 1994 for tank 241-SX-108. The data from the TC tree in riser \#15 is considered bad and has not been included. There is about a $30 \mathrm{~F}^{\circ}$ spread in the data at the two lower TCS which are in the waste. The data does not correlate with distance from the center of the tank. A recent core sample from this tank shows that the sludge is very dry.

Figure 5 shows the 5 year averaged data and the data for all the trees taken on Apri1 8, 1996 for tank 241-SX-114. All of the data is fairly compact, except for the TCs in riser \#18 which are much lower, with about a 15 to $20 \mathrm{~F}^{\circ}$ spread.

\subsection{CASES ANALYZED}

Because the SX tanks on the High-Heat list have been interim stabilized for more than 10 years, steady-state solutions of the thermal equations are sufficient to characterize the temperature conditions in each tank. In all of the figures showing tank temperatures versus depth, the depth is measured from 
Rev. 0

the bottom of the tank at the location of the TC trees. The depth of the waste reported (Hanlon 1994 and Tran 1993) is at the center of the tank. Three cases were analyzed, a bench mark case and two dry out cases.

\subsection{BENCH MARKED AGAINST DATA}

The total heat load and waste thermal conductivity were adjusted to match measured temperature profiles at the TC locations. Dry soil properties were assumed for the soil surrounding the tank. This case represents what the conditions most likely are currently in and surrounding the tank.

\subsection{DRY OUT CASES}

Two cases were analyzed for dry conditions in the tanks. The first one represents what conditions might exist as the tank drys from the center out. Dry soil properties were assumed for the soil surrounding the tank. The total heat load assumed was the same as in the bench mark case. A cylinder of waste of $10 \mathrm{ft}$ radius at the center of tank was assumed to have dry waste thermal conductivity, with the remainder of the waste having the same thermal conductivity as for the bench mark case.

The second case represents what temperatures might exist as the tank drys out with average soil properties surrounding the tank. A cylinder of waste of $10 \mathrm{ft}$ radius at the center of tank was assumed to have dry waste thermal conductivity. The total heat load and waste thermal conductivity outside the dry cylinder in the center was adjusted to match measured temperature profiles at the TC locations.

\subsection{THERMAL ANALYSIS RESULTS}

Table 3 gives the total heat source and thermal conductivities used in the cases, and the calculated maximum temperatures in the waste and concrete. The maximum concrete temperature occurs in the center at the bottom of the waste. Note that for all cases the maximum concrete temperature is below $350^{\circ} \mathrm{F}$, which is the OSR Safety Limit for concrete in SSTs. 
WHC-SD-WM-ER-577

Rev. 0

Table 3. Total Heat Source, Soil and Waste Conductivity, and Maximum Waste and Concrete Temperature.

\begin{tabular}{|c|c|c|c|c|c|}
\hline \multirow{2}{*}{ Tank /case } & \multirow{2}{*}{$\begin{array}{c}\text { Total Heat } \\
\text { Source } \\
(\text { Btu/h) }\end{array}$} & \multirow{2}{*}{$\begin{array}{l}\text { Soil Thermal } \\
\text { Conductivity } \\
\left.\text { Btu/(h ft }{ }^{\circ} \mathrm{F}\right)\end{array}$} & \multirow{2}{*}{$\begin{array}{l}\text { Waste Thermal } \\
\text { Conductivity } \\
\text { outer/center } \\
\left.\text { Btu/(h ft }{ }^{\circ} \mathrm{F}\right)\end{array}$} & \multicolumn{2}{|c|}{$\begin{array}{c}\text { Maximum Temperature } \\
\left({ }^{\circ} \mathrm{F}\right)\end{array}$} \\
\hline & & & & Waste & Concrete \\
\hline \multicolumn{6}{|l|}{$S X-108$} \\
\hline$B M^{1}$ & 53,800 & 0.152 & $0.25 / 0.25$ & 243 & 243 \\
\hline Dry $1^{2}$ & 53,800 & 0.152 & $0.25 / 0.083$ & 327 & 312 \\
\hline Dry $2^{3}$ & 75,400 & 0.484 & $0.35 / 0.083$ & 343 & 304 \\
\hline \multicolumn{6}{|l|}{$5 x-114$} \\
\hline$B M^{1}$ & 35,900 & 0.152 & $0.32 / 0.32$ & 214 & 214 \\
\hline Dry $1^{2}$ & 35,900 & 0.152 & $0.32 / 0.083$ & 290 & 266 \\
\hline Dry $2^{3}$ & 54,400 & 0.484 & $0.45 / 0.083$ & 321 & 260 \\
\hline
\end{tabular}

1: Bench Marked Case

2: Dry Soil Thermal Conductivity

3: Average Soil Thermal Conductivity

\subsection{TANK 241-SX-108}

There are eight TC trees in tank 241-SX-108. However, only tree \#2 (riser 10) and tree \#8 (riser 19) are currently being recorded on a regular basis. There are four TCs on each tree. The distances of the TCs from the bottom of the tank at the tree location are: $0.50 \mathrm{ft}, 1.92 \mathrm{ft}, 3.33 \mathrm{ft}$, and $4.67 \mathrm{ft}$ (TRAN 1993). The waste level in tank 241-SX-108 was about $3.1 \mathrm{ft}$ at the center of the tank during the time period over which the temperatures were averaged, therefore the two TCS at the top of the trees are in the tank airspace. An average ajrflow of $462 \mathrm{scfm}$ obtained from psychrometric data from JuTy 1994 through June 1995 was used in the model.

Figure 6 shows the calculated waste temperatures at the TC tree locations and the center of the tank for the bench marked case. The calculated dome air-space temperature, which represents an average for the entire dome air-space, is about $140^{\circ} \mathrm{F}$ which is close to the measured dome temperatures. A comparison with the measured data at tree \#2 (30 ft from the center of the tank) is close. The model predicts higher temperatures at TC tree \#8 (20 ft from the center of the tank) than the measured data. This may be due to nonuniform heat load distribution or nonhomogeneous thermal conductivities in the waste.

Figure 7 shows the calculated waste temperatures at the TC tree locations and the center of the tank for the two dry center waste cases. For the two dry center cases the maximum temperatures which occur at the center of 
Rev. 0

the tank increase 85 to $100 \mathrm{~F}^{0}$ above the bench marked maximum temperature. The maximum temperature in the concrete increases about 60 to $70 \mathrm{~F}^{\circ}$. Also note that the maximum temperature in the waste occurs about $0.8 \mathrm{ft}$ above the bottom of the tank. The main point to be noted from these plots is that the temperatures at the TC tree locations do not vary much for the three cases. Thus as the tank drys from the center out the increase in temperatures at the center of the tank are not reflected at the TC tree locations.

\subsection{TANK $S X-114$}

There are eight TC trees in tank 241-5X-114. However, only tree \#2 (riser 10) and tree \#8 (riser 19) are currently being recorded on a regular basis. There are eight TCS on each tree and, since the TC elevations have not been verified (Tran 1993), the spacing from the bottom of the tank is assumed the same as for tank 241-SX-112. The distances of the TCs from the bottom of the tank at the tree location are: $0.50 \mathrm{ft}, 1.17 \mathrm{ft}, 1.92 \mathrm{ft}, 2.58 \mathrm{ft}, 3.33$ $\mathrm{ft}, 4.00 \mathrm{ft}, 4.67 \mathrm{ft}$, and $5.33 \mathrm{ft}$ (TRAN 1993). The waste level in tank 241-SX-114 has been at about $5.5 \mathrm{ft}$ at the center of the tank for the last six years, therefore the top TC of the trees may be in the tank air-space. An average airflow of $312 \mathrm{scfm}$ obtained from psychrometric data from JuTy 1994 through June 1995 was used in the model.

Figure 8 shows the calculated waste temperatures at the TC tree locations and the center of the tank for the bench marked case. The calculated dome air-space temperature, which represents an average for the entire dome air-space, is about $140^{\circ} \mathrm{F}$ which is about 5 to $10 \mathrm{~F}^{\circ}$ above the measured dome temperatures. A comparison with the measured data at tree \#2 (30 ft from the center of the tank) is close. The model predicts higher temperatures at TC tree $\# 8$ (20 ft from the center of the tank) than the measured data. This may be due to nonuniform heat load distribution or nonhomogeneous thermal conductivities in the waste.

Figure 9 shows the calculated waste temperatures at the TC tree locations and the center of the tank for the two dry center waste cases. For the two dry center cases the maximum temperatures which occur at the center of the tank increase 80 to $100 \mathrm{~F}^{\circ}$ above the bench marked maximum temperature.

The maximum temperature in the concrete increases only about $50 \mathrm{~F}^{\circ}$. Also note that the maximum temperature in the waste occurs about $1.5 \mathrm{ft}$ above the bottom of the tank. The main point to be noted from these plots is that the temperatures at the TC tree locations do not vary much for the three cases. Thus as the tank drys from the center out the increase in temperatures at the center of the tank are not reflected at the TC tree locations.

\subsection{CONCLUSIONS}

If tanks 24l-SX-108 and 241-SX-114 become dry from the center outward and the thermal conductivity decreases to the very dry condition of $0.083 \mathrm{Btu} /\left(\mathrm{h} \mathrm{ft}{ }^{\circ} \mathrm{F}\right)$ the temperature in the center of the tank can increase around $100 \mathrm{~F}^{\circ}$ while the TC temperatures at the tree in riser $19(20 \mathrm{ft}$ from 
center of tank) increase only around $5 F^{\circ}$. This increase of $5 F^{\circ}$ is less than the seasonal variation that occurs in these tanks.

The maximum waste temperature for both tanks for all cases is less than $350{ }^{\circ} \mathrm{F}$. The maximum concrete temperature for tank 241-5X-108 exceeds $300^{\circ} \mathrm{F}$ for the dry waste center cases. The concrete exceeds $300^{\circ} \mathrm{F}$ in the bottom center of the tank for a radius of about $5 \mathrm{ft}$. The maximum concrete temperature for tank 241-SX-114 does not exceed $300{ }^{\circ} \mathrm{F}$ for all cases.

\subsection{RECOMMENDATIONS}

Tanks 241-SX-108 and 241-SX-114 should continue to have their temperatures measured in risers 10 and 19 on a regular basis. The current temperatures should be compared with previous measurements during the same time of the year, taking into account the seasonal variation of the ambient temperature. This will give some indication if the temperatures in the tank are increasing due to the thermal conductivity decreasing in the waste. 
WHC-SD-WM-ER-577

Rev. 0

Figure 1. Entire Thermal Model for 1 Million gal Single-Shell Tank.

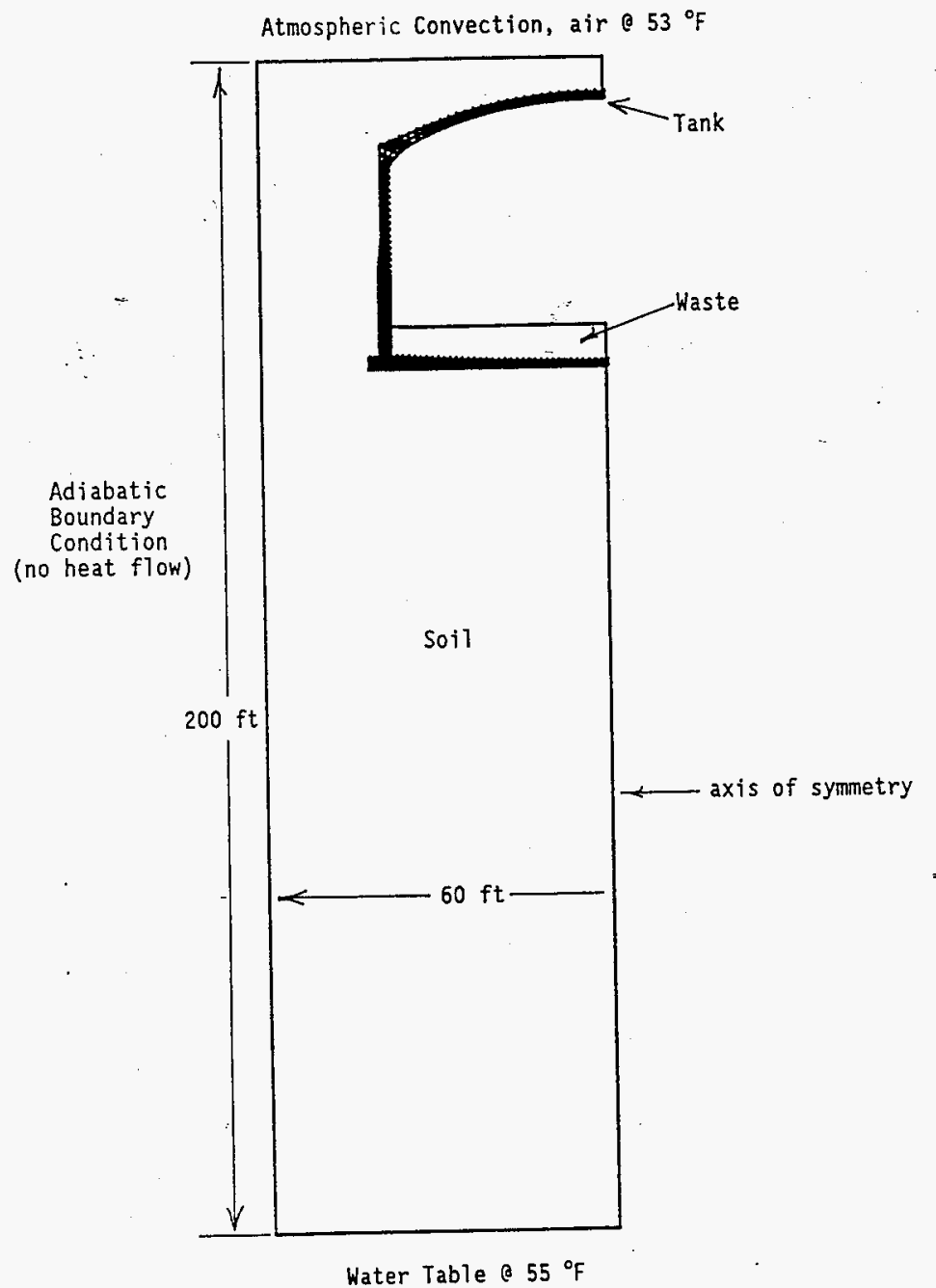


WHC-SD-WM-ER-577

Rev. 0

Figure 2. SX-Tank Thermal Model.

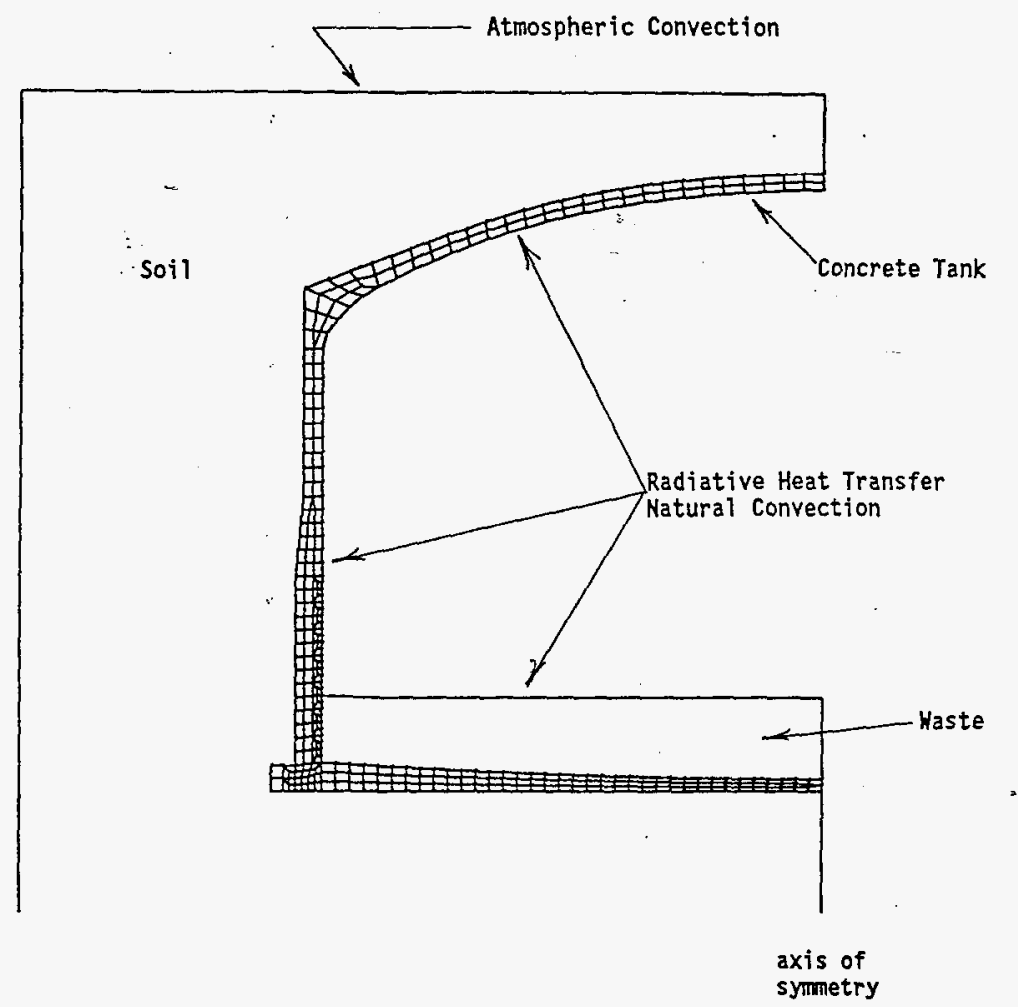




\section{WHC-SD-WM-ER-577 \\ Rev. 0}

Figure 3. SX-Tank Thermal Model with $10 \mathrm{ft}$ radius dry waste in Center of Tank.

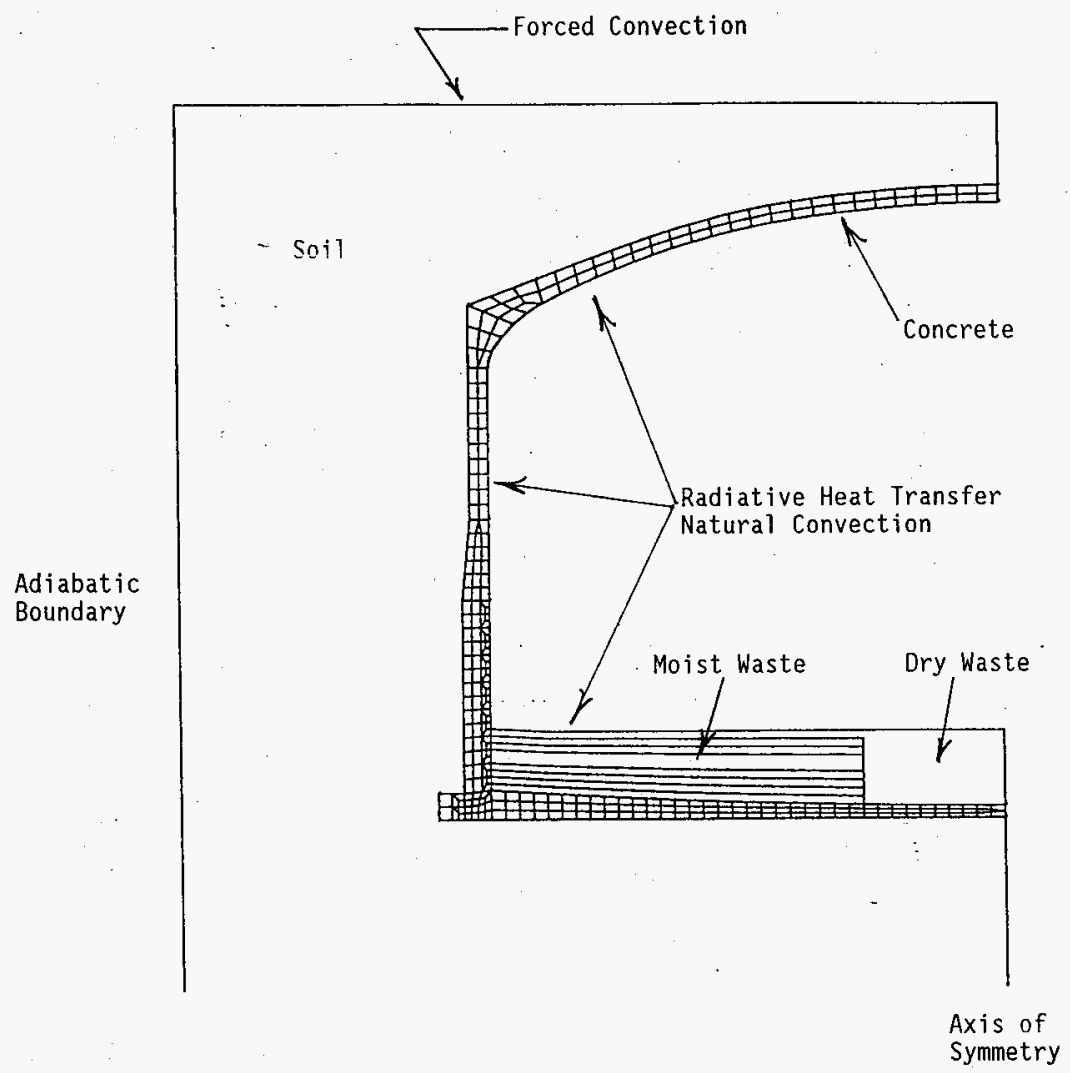


WHC-SD-WM-ER-577

Rev. 0

Figure 4. Tank SX-108 Measured Temperatures.

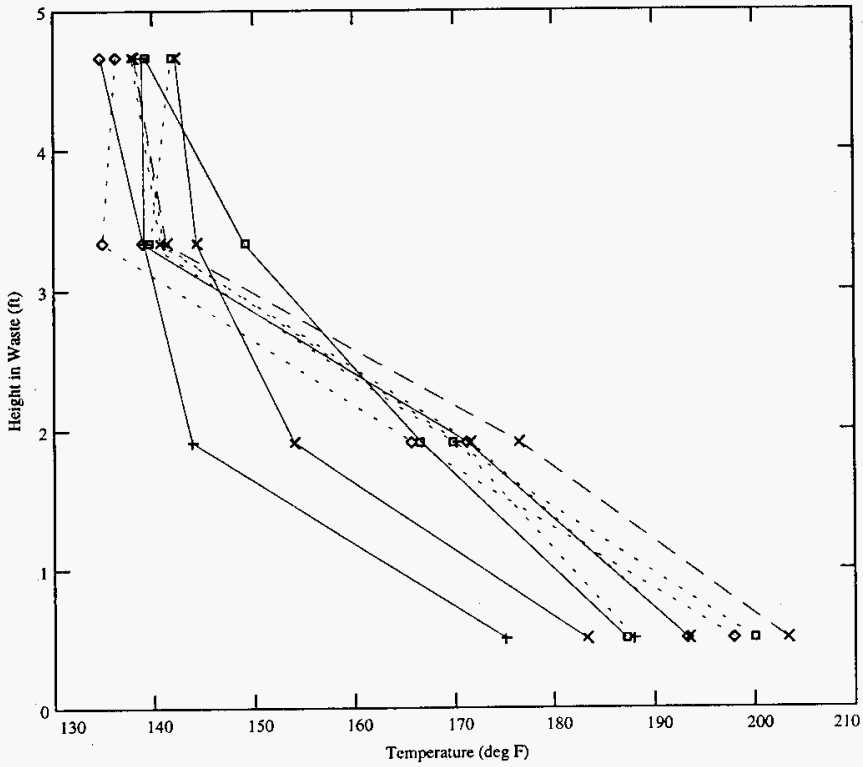


WHC-SD-WM-ER-577

Rev. 0

Figure 5. Tank 5X-114 Measured Temperatures.

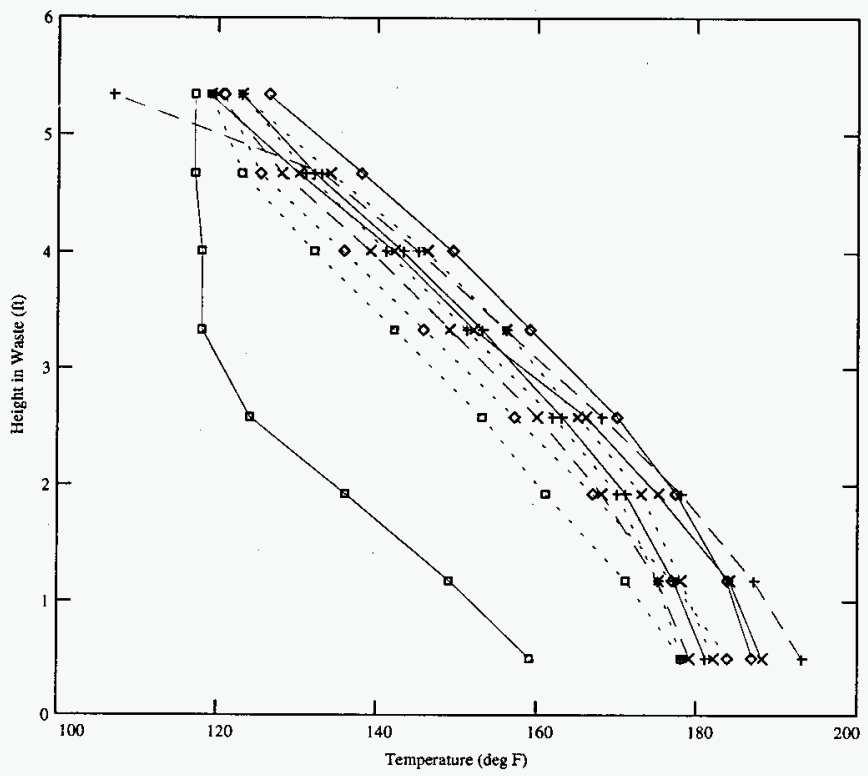


WHC-SD-WM-ER-577

Rev. 0

Figure 6. Tank SX-108 Calculated Temperature. (Benchmark Case)

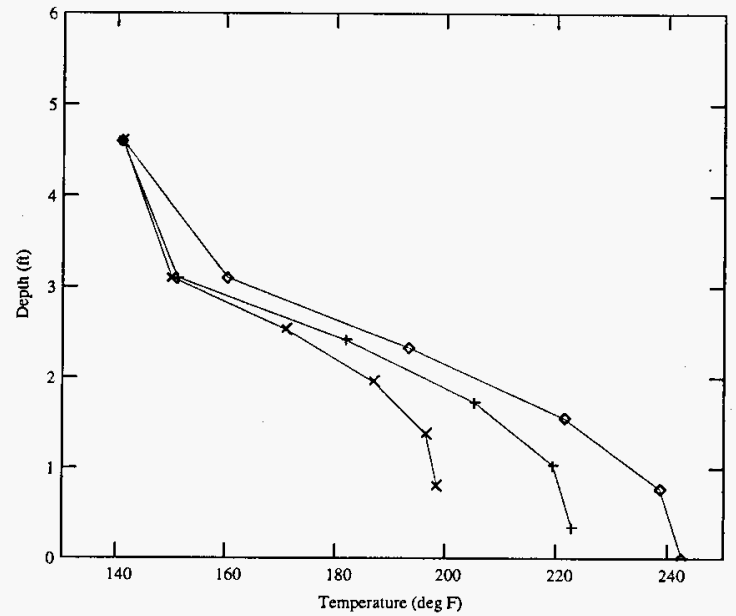

*- Riser $10 \mathrm{TC}$ tree $\# 2$ : $30 \mathrm{ft}$ from center

+ Riser 19 TC uree \#8: $20 \mathrm{ft}$ from center

$\rightarrow$ Tank center 
WHC-SD-WM-ER-577

Rev. 0

Figure 7. Tank SX-108 Calculated Temperatures. (Dry Center Cases)

Dry Center in Waste with Dry Soil

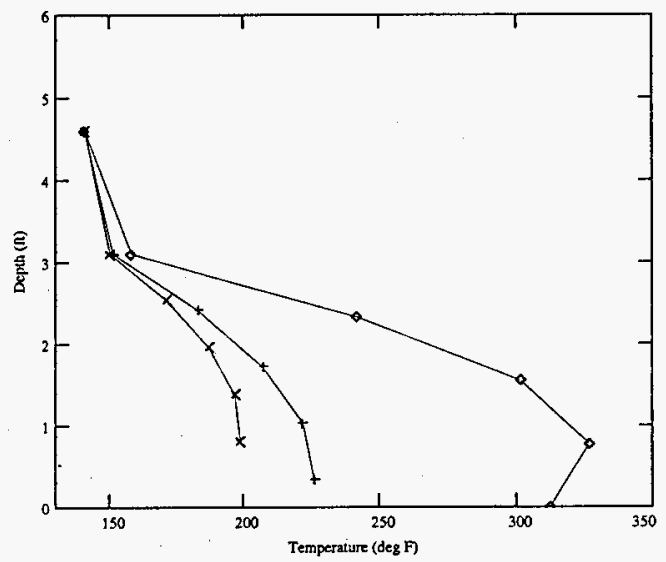

* Riser 10 TC tree \#2: $30 \mathrm{ft}$ from center

+ Riser $19 \mathrm{TC}$ tree \#8: $20 \mathrm{ft}$ from center

- Tank center

Dry Center in Waste with Average Soil

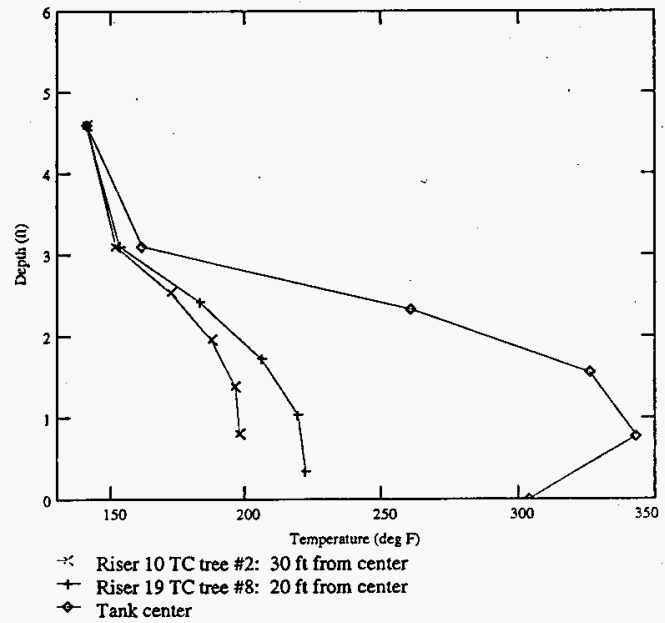


WHC-SD-WM-ER-577

Rev. 0

Figure 8. Tank SX-114 Calculated Temperature.

(Benchmark Case)

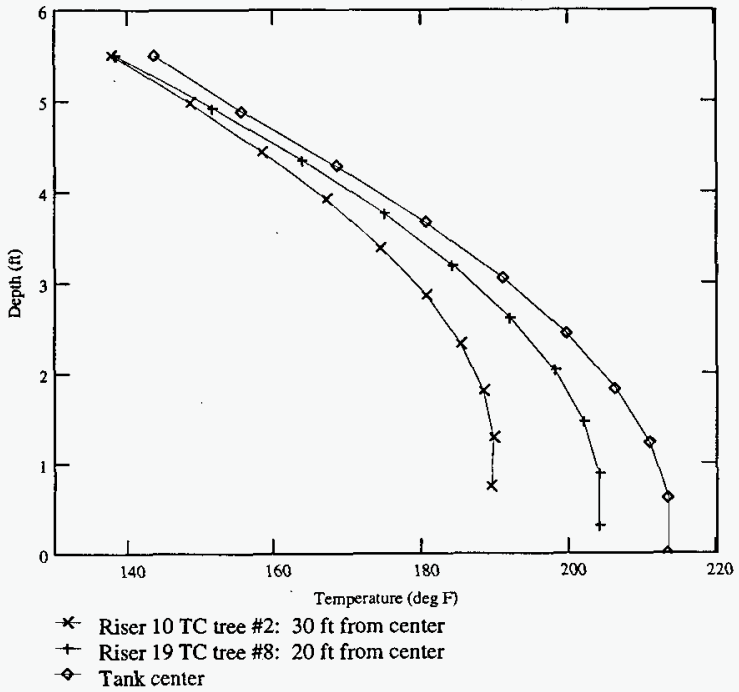


WHC-SD-WM-ER-577

Rev. 0

Figure 9. Tank 5X-114 Calculated Temperatures.

(Dry Center Cases)

Dry Center in Waste with Dry Soil

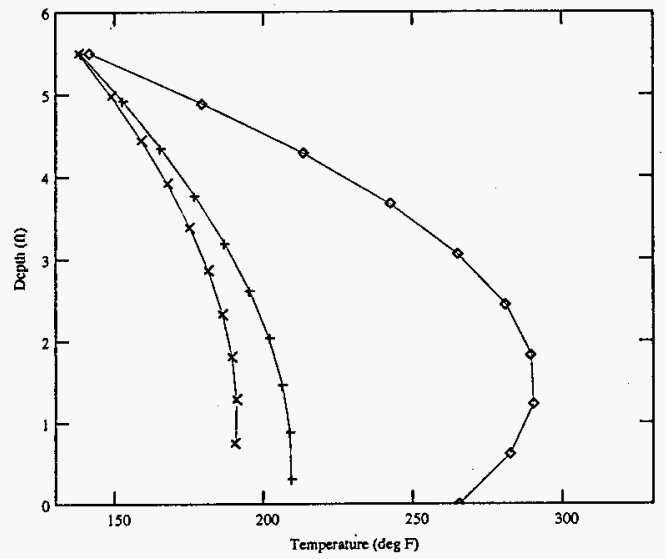

* Riser $10 \mathrm{TC}$ tree \#2: $30 \mathrm{ft}$ from center

- Riser 19 TC tree $\# 8: 20$ ft from center

- Tank center

. Dry Center in Waste with Average Soil

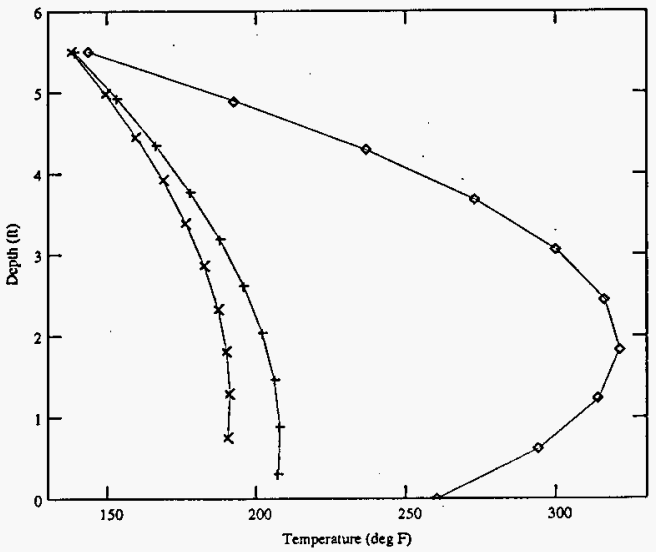

* Riser 10 TC tree \#2: $30 \mathrm{ft}$ from center

+ Riser 19 TC tree \#8: $20 \mathrm{ft}$ from center

- Tank center 
Rev. 0

\subsection{REFERENCES}

Bander, T. J., August 1992, Thermal History of Tank 241-C-106, WHC-SD-WM-ER-161, Rev. 0, Westinghouse Hanford Company, Richland, Washington.

Bander, T. J., October 1994, Evaluation of Heat Sources in High-Heat SingleShell Tanks, WHC-SD-WM-ER-333, Rev. 0, Westinghouse Hanford Company, Richland, Washington.

Bouse, D. G., July 1975, Thermal Conductivity of Hanford Waste Tank Solids and SX Tank Farm Soi7 Samples, ARH-CD-378, Atlantic Richfield Hanford Company, Richland, Washington.

Dougherty, L. F., 1996, Single-Shell Tanks Interim Operational Requirements, WHC-SD-WM-0SR-005, Rev. 0-C, Westinghouse Hanford Company, Richland, Washington.

Gibby, R. D., 1989, "High Heat Single-She11 Tanks," Internal Memo 13316-89-042 to V. D. Maupin, dated April 20, 1989, Westinghouse Hanford Company, Richland, Washington.

Hanlon, B. M., February 1996, Waste Tank Summary Report for Month Ending December 31, 1995, WHC-EP-0182-93, Westinghouse Hanford Company, Richland, Washington.

Kreith, F., 1959, Principles of Heat Transfer, International Textbook Company, Scranton, Pennsylvania.

PATRAN, October 1990, PATRAN Plus User Manuals, Release 2.5, PDA Engineering, PATRAN Division, Costa Mesa, California.

P/THERMAL, Apri1 1991, P/THERMAL Release 2.5 Notes, PDA Engineering, PATRAN Division, Costa Mesa, California.

P/VIEWFACTOR, April 1991, P/VIEWFACTOR Release 2.5 Notes, PDA Engineering, PATRAN Division, Costa Mesa, California.

Stone, W. A., J. M. Thorp, 0. P. Gifford, and D. J. Hoitink, June 1983, Climatological Summary for the Hanford Area, PNL-4622, Pacific Northwest Laboratories, Richland, Washington.

Tran, T. T., September 1993, Thermocouple Status Single-Shell and Double-Shell Waste Tanks, WHC-SD-WM-TI-553, Westinghouse Hanford Company, Richland, Washington. 
WHC-SD-WM-ER-577

Rev. 0

APPENDIX A. SX Tank Farms Exhauster Process Test 
From: Plant Systems Technical Basis

Phone: $376-0205 \mathrm{HO}-34$

Date: $\quad$ October 25, 1995

Subject: SX TANK FARMS EXHAUSTER PROCESS TEST

To:

S. H. Rifaey

T4-07

$\begin{array}{ll}\text { cc: T. J. Bander } & H 0-34 \\ \text { T. D. Kaiser } & T 4-07 \\ \text { J. R. Kriskovich } & 52-24 \\ \text { D. M. Ogden } & H 0-34 \\ \text { J. G. Propson } & 52-02 \\ \text { E. A. Smith } & H 5-56 \\ \text { BAC File/LB } & \end{array}$

References: (1) WHC, 1995, Tank Farms Interim Operational Safety Requirements, Rev. 0, WHC-SD-WM-0SR-018, Rev. 0, Westinghouse Hanford Company, Richland, Washington.

(2) Bander, T. J., and C. A. Hinman, 1994, Evaluation of Heat Sources in High-Heat Single-She7l Tanks, WHC-SD-WM-ER-333, Rev. 0, Westinghouse Hanford Company, Richland, Washington.

(3) WHC, 1994, Supporting Document for the Historical Tank Content Estimate for SX Tank Farm, WHC-SD-WM-ER-324, Rev. 0, Westinghouse Kanford Company, Richland, Washington.

The exhauster/sludge cooler for the SX tank farms no longer meets current regulations for discharge to the environment. In addition, it requires frequent maintenance, and has poor reliability. If it must be operated for years into the future then resources must be committed to upgrade the system to meet current environmental discharge regulations and to improve the maintainability and reliability of the system. Work is in progress to plan a process test to investigate the possibility of placing the SX tank farm in a passive ventilation mode. This memo is an interim report on the analyses that are underway to resolve the thermal and flammable gas issues associated with conducting this test.

The basic concept of the test is to turn the exhauster off for some predefined period of time and carefully monitor the transducers that are installed in the tank (both thermocouples and hydrogen monitoring system). If the test is properly designed and executed then enough empirical data may be gathered from this type of process test to evaluate the effect of permanent shutdown of the exhauster. At the very least enough data may be acquired to justify conducting another test of longer duration. 
Page 2

October 25, 1995

Current models for both temperatures and hydrogen concentrations predict that if the exhauster for the SX tank farms is turned off both the temperatures in the waste and probably hydrogen concentrations in the dome space will exceed current limits. The peak waste and structural temperatures aren't measured, but are inferred from the measured temperatures based on a thermal model of the tank. The hydrogen concentrations in the tank dome space are directly measured.

This process test will provide data that can be used to upgrade (reduce conservatism) the thermal models for the tanks in the $S X$ farm (particularly the hotter tanks SX-114 and SX-108). The direct data from the hydrogen monitoring system can also be used to upgrade the hydrogen generation/distribution model for the hydrogen generating tanks in the SX tank farms.

One of the tasks that was undertaken was a recalculation of the heat load in tanks SX-114 and SX-108 based on a larger data set than was used in the initial screening calculations reported in Reference 2 . The methodology and models used were the same. The result of this is a revised estimate for total heat generation in SX-114 of 65,000 Btu/hr. Based on this heat load shutting off the ventilation system will result in an initial rate of rise of the peak waste temperature of $8{ }^{\circ} \mathrm{F} /$ month.

While the composition of the interstitial liquid in tank $\$ X-114$ isn't known some of the information from Reference 3 would indicate that the principal solute is sodium nitrate. This doesn't have nearly as much of a depressant effect on the vapor pressure as sodium hydroxide, and so vapor pressure as a function of temperature for the liquid in the tank has been taken to be $85 \%$ of the value for pure water. This value is needed to predict when saturated conditions occur in the tank.

One of the requirements of this test is that none of the limits that govern the operation of the tanks being tested will be violated. The waste temperature limit is $300^{\circ} \mathrm{F}$, but there is also the requirement that a tank that is projected to boil be placed on active ventilation. Preliminary thermal analysis predicts that a point within tank $S X-114$ will reach the local saturation temperature about 60 days after the ventilation system is shut down, and the volume that is at the local saturation temperature is projected to exceed 8000 gallons within 90 days of shutting down the ventilation system. The exact meaning of the word "boil" in the existing single shell tank operating specification is not defined, and the original intent may have been to describe continuous active evolution of steam. But technically, when a fluid reaches the saturation temperature it is "boiling."

Current models predict that if the ventilation system for SX-114 is permanently shut down and the contents of SX-114 are allowed to heat up temperatures will be reached that will drive off the interstitial liquid that is currently trapped in the sludge in some reasonably short period of time (less than a decade). If this occurs then the effective thermal conductivity of the waste in the tank is expected to decline significantly. Preliminary assessment of this condition indicates that the temperature of 
Rev. 0

S. H. Rifaey

Page 3

October 25, 1995

both the waste and the concrete can be expected to exceed $400^{\circ} \mathrm{F}$. This of course violates both the waste temperature limit and the Tank Structural Temperature Limit which is $350^{\circ} \mathrm{F}$.

There is also a set of proposed operating limits that are contained in Reference 1. I believe that there is a commitment to implement these limits in the near term although I don't believe that final approval has been obtained at this time. One of the provisions in Reference 1 that will affect this test if the limits are implemented as currently presented is the provision that sludge temperatures be maintained at or below established baseline temperatures. Established baseline temperatures in this context are taken to mean "recent" operating values. When and if this provision is implemented it will effectively prohibit any action that would tend to increase the sludge temperatures. This would of course include the process test itse]f.

There may be a preferred time of year to conduct this test. The preferred time depends on whether it is deemed most desirable to have as long a test as possible, or to maximize the sensitivity of the instruments used to monitor the test. There is a yearly cycle to the waste temperatures based on the winter-summer temperature variation of the inlet air used for cooling the tanks. Peak temperatures in the waste occur in the last quarter of the calendar year. Minimum temperatures occur in the spring, typically around March or April. The capability to discriminate temperature rise trends from normal variation will be enhanced if the expected/normal behavior of the tank would be a decreasing trend in temperature. From this viewpoint the best time of the year to start the test is probably during the month of November.

It is expected that the length of time that the test can be conducted will be governed by the time required to reach temperature limits (saturation) this would argue that the test is best started in the March-April time frame, since the waste will be at the yearly low temperature (presuming reliable continuous exhauster operation during the winter months) during this time frame.

Based on preliminary thermal evaluation tank $S X-114$ can be expected to reach the saturation temperature for the liquid in the tank within 60 days after the exhaust system is turned off if the tank is at "average" conditions. Since the yearly temperature swings in the tank are on the order of $12-16^{\circ} \mathrm{F}$ and the initial rate of rise for the temperatures is around $8{ }^{\circ} \mathrm{F} /$ month it is possible that the length of the test could be extended to around 90 days if it was conducted around the time that the temperatures reach their yearly low.

Initial calculation of the hydrogen concentrations, using an existing analytical model, show that the equilibrium hydrogen concentration depends on the boundary condition chosen. One reasonable but limiting boundary condition shows that the limit ( $1 \%$ by volume) is exceeded. A different limiting case boundary condition shows that it's not. It is expected that the data from the installed hydrogen monitoring system will be closely monitored during the test, and the ventilation system will be restarted if 
Rev. 0

S. H. Rifaey

$74010-95-B A C-042$

Page 4

October 25, 1995

it is seen to approach the limit specifjed in the test plan. The limit for the test is expected to be set at some level below the normal operating limit to allow adequate time to restart the system.

This exhauster system services 13 of the 15 tanks in the SX tank farms. The high heat status of tank SX-114 and possibly tank SX-108 make it unlikely that the results of the proposed process test will support the complete shutdown of the exhauster in this tank farm. A process test should resolve the issue of whether or not the hydrogen watch list tanks require active ventilation. There are also several other tanks in the farm that are on active ventilation and probably don't need it. The current flow for the whole farm is around $3000 \mathrm{cfm}$. This flow could possibly be reduced to around $1000 \mathrm{cfm}$ by isolating some of the tanks and still meet the cooling needs of the hot tanks. A process test can give valuable information about the tanks in the $S X$ farm that would allow informed decisions to be made concerning changes/upgrades to the farm ventilation systems. It is unlikely that the information obtained will support passive ventilation of all the tanks in the SX farm.

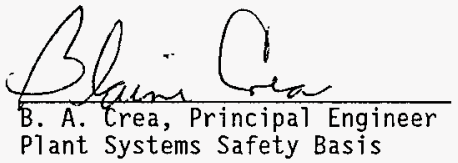

bab
$\frac{\text { Malm }}{\text { D. M. Ogden }}$
Date: 10126195
Plant Systems Safety Basis 


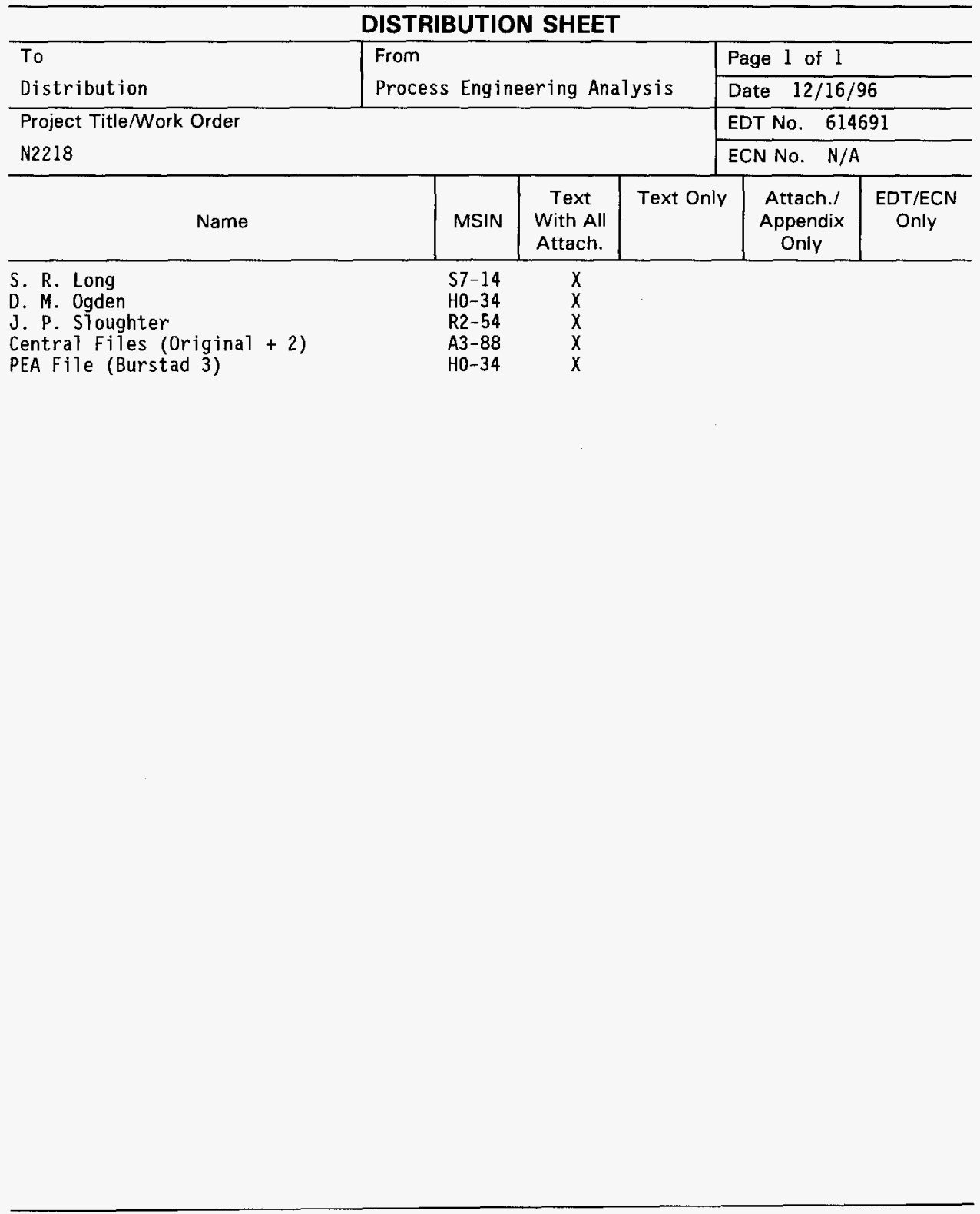

